\title{
Antidipsogenic effects of central adenosine-5'-triphosphate
}

\author{
D.R.G. de Faria, J.S. Santana, J.V. Menani and P.M. de Paula \\ Departamento de Fisiologia e Patologia, Faculdade de Odontologia de Araraquara, Universidade \\ Estadual Paulista, Araraquara, SP, Brasil \\ Correspondence to: P.M. de Paula, Departamento de Fisiologia e Patologia, Faculdade de Odontologia \\ de Araraquara, UNESP, 14801-903 Araraquara, SP, Brasil \\ Fax: +55-16-3301-6488. E-mail: depaula@foar.unesp.br
}

\begin{abstract}
Besides other physiological functions, adenosine-5'-triphosphate (ATP) is also a neurotransmitter that acts on purinergic receptors. In spite of the presence of purinergic receptors in forebrain areas involved with fluid-electrolyte balance, the effect of ATP on water intake has not been investigated. Therefore, we studied the effects of intracerebroventricular (icv) injections of ATP (100, 200 and $300 \mathrm{nmol} / \mu \mathrm{L}$ ) alone or combined with DPCPX or PPADS (P1 and P2 purinergic antagonists, respectively, 25 $\mathrm{nmol} / \mu \mathrm{L}$ ) on water intake induced by water deprivation. In addition, the effect of icv ATP was also tested on water intake induced by intragastric load of $12 \% \mathrm{NaCl}(2 \mathrm{~mL} / \mathrm{rat})$, acute treatment with the diuretic/natriuretic furosemide $(20 \mathrm{mg} / \mathrm{kg})$, icv angiotensin II $(50 \mathrm{ng} / \mu \mathrm{L})$ or icv carbachol (a cholinergic agonist, $4 \mathrm{nmol} / \mu \mathrm{L})$, on sodium depletion-induced $1.8 \% \mathrm{NaCl}$ intake, and on food intake induced by food deprivation. Male Holtzman rats (280-320 g, N =7-11) had cannulas implanted into the lateral ventricle. Icv ATP (300 nmol/ $\mu \mathrm{L})$ reduced water intake induced by water deprivation (13.1 \pm 1.9 vs saline: $19.0 \pm 1.4 \mathrm{~mL} / 2 \mathrm{~h}$; $\mathrm{P}<0.05)$, an effect blocked by pre-treatment with PPADS, but not DPCPX. IcV ATP also reduced water intake induced by $\mathrm{NaCl}$ intragastric load $(5.6 \pm 0.9$ vs saline: $10.3 \pm 1.4 \mathrm{~mL} / 2 \mathrm{~h} ; \mathrm{P}<0.05)$, acute furosemide treatment $(0.5 \pm 0.2$ vs saline: $2.3 \pm 0.6 \mathrm{~mL} / 15 \mathrm{~min} ; \mathrm{P}$ $<0.05)$, and icv angiotensin II (2.2 \pm 0.8 vs saline: $10.4 \pm 2.0 \mathrm{~mL} / 2 \mathrm{~h} ; \mathrm{P}<0.05)$, without changing icv carbachol-induced water intake, sodium depletion-induced $1.8 \% \mathrm{NaCl}$ intake and food deprivation-induced food intake. These data suggest that central ATP, acting on purinergic $\mathrm{P} 2$ receptors, reduces water intake induced by intracellular and extracellular dehydration.
\end{abstract}

Key words: Water intake; ATP icv; Purinergic receptors; Angiotensin II; Carbachol; Ingestive behavior

Presented at the IV Miguel R. Covian Symposium, Ribeirão Preto, SP, Brazil, May 23-25, 2008.

Research supported by FAPESP (\#07/50647-0).

Received September 13, 2008. Accepted January 20, 2009

\section{Introduction}

A role for adenosine-5'-triphosphate (ATP) as an extracellular signaling molecule and neurotransmitter was first proposed by Burnstock (for a review, see Ref. 1). ATP binds to two classes of purinergic receptors: the ionotropic P2X and the metabotropic P2Y receptors (2). However, ATP can be easily converted to adenosine that binds to $P 1$ purinergic receptors (classified as $\mathrm{A} 1, \mathrm{~A} 2$, and $\mathrm{A} 3$ ) $(3,4)$. Functional studies have shown that central purinergic mechanisms are involved in cardiac, respiratory and thermal regulation (5-16). However, there is little information on the role of purinergic mechanisms in behavioral responses (17), including pathways involved in intracellular and extracellular thirst.

Immunohistochemical studies have demonstrated the presence of purinergic receptors in several areas of the central nervous system (CNS), which are involved in fluidelectrolyte balance $(18,19)$, including circumventricular organs that are areas strongly involved in the control of sodium and water intake (20). Therefore, an important question that remains is whether purinergic receptors in forebrain areas are involved in the control of water and sodium intake. In the present study, we investigated the 
effects of intracerebroventricular (icv) injections of ATP alone or combined with 8-cyclopentyl-1,3-dipropylxanthine (DPCPX, an adenosine A1 receptor antagonist) or pyridoxalphosphate-6-azophenyl-2',4'-disulfonic acid (PPADS, a purinergic $\mathrm{P} 2$ receptor antagonist) on water intake induced by $24 \mathrm{~h}$ of water deprivation (a model that mixes intra- and extracellular dehydration) $(21,22)$. In addition, we also tested the effects of icv ATP on water intake induced by intragastric gavage with $12 \% \mathrm{NaCl}$ (a model of intracellular dehydration) (23), acute treatment with the diuretic/natriuretic furosemide (a model of extracellular dehydration) $(24,25)$, icv angiotensin II (ANG II, the main mechanism activated by extracellular dehydration to induce thirst) (21), and icv carbachol (a cholinergic agonist suggested to activate the same central mechanisms involved in intracellular dehydration-induced thirst) $(26,27)$. To determine the specificity of central ATP for the control of water intake in comparison to another type of ingestive behavior, we also tested the effects of icv ATP on sodium depletion-induced $1.8 \% \mathrm{NaCl}$ intake and on food deprivation-induced food intake.

\section{Material and Methods}

\section{Animals}

Male Holtzman rats weighing 280-310 g were used. The animals were housed in individual stainless steel cages with free access to a normal sodium diet (Guabi Rat Chow, Brazil), water and $1.8 \% \mathrm{NaCl}$ solution and maintained under controlled conditions $\left(23 \pm 2^{\circ} \mathrm{C}\right.$, humidity at $55 \pm 10 \%$ and on a 12-h light/dark cycle with lights on at 7:00 am). Standard Guabi rodent pellets ( $0.5 \%$ sodium) and tap water were available ad libitum unless otherwise stated. All experiments were started between 8:00 and 9:00 am at least 5 days after surgery. The experimental protocols used in the present study were approved by the Ethics Committee for Animal Care and Use of the Dental School of Araraquara, UNESP, Brazil, and followed the recommendations of the Brazilian College of Animal Experimentation (COBEA) and the National Institutes of Health Guide for the Care and Use of Laboratory Animals (NIH publications No. 80-23, 1996, USA). All efforts were made to minimize animal discomfort and the number of animals used.

\section{Surgery for cerebral cannulas}

Rats were anesthetized with an intraperitoneal injection of ketamine $(80 \mathrm{mg} / \mathrm{kg}$ body weight; Cristália, Brazil) combined with xylazine $(7 \mathrm{mg} / \mathrm{kg}$ body weight; Agener União, Brazil), and placed in a Kopf stereotaxic instrument. The skull was leveled between the bregma and lambda. A stainless steel guide cannula $(10 \times 0.7 \mathrm{~mm}$ OD) was implanted into the lateral ventricle (LV) using the following coordinates: $0.3 \mathrm{~mm}$ caudal to the bregma, $1.6 \mathrm{~mm}$ lateral to the midline, and $3.6 \mathrm{~mm}$ below the bone. The cannula was secured to the top of the skull with dental acrylic resin and two jeweler screws. Insertion of a close-fitting stylet kept the lumen free of debris and clots. A prophylactic presurgical dose of penicillin (30,000 IU) was given intramuscularly. Immediately after surgery, the rats received intramuscular injections of $1 \%$ cetoprophen, an analgesic drug $(30 \mu \mathrm{L})$. Rats were allowed to recover from surgery for at least 5 days.

\section{Intracerebral injections}

Single-pulse intracranial injections were made after gently removing the animal from its cage, replacing the stylet with an injector that protruded $2.0 \mathrm{~mm}$ beyond the tip of the guide cannula and that was connected by PE-10 tubing to a $10-\mu \mathrm{L}$ syringe, and injecting a total volume of $1.0 \mu \mathrm{L}$ over a period of $20 \mathrm{~s}$. Stylet and injector were always wiped with cotton soaked in $70 \%$ alcohol between injections. After the injection, the injector was removed and replaced with the stylet, and the animal was returned to its cage for observation of its behavior.

\section{Drugs}

ATP (a natural P2 receptor agonist), DPCPX (an adenosine $A 1$ receptor antagonist), PPADS (a $P 2$ purinergic receptor antagonist), ANG II, and carbachol were purchased from Sigma. All drugs were freshly dissolved in $0.9 \%$ saline, except DPCPX that was dissolved in saline containing $5 \%$ dimethyl sulfoxide (Sigma, USA). ATP was administered into the LV at the dose of 100, 200, and 300 $\mathrm{nmol} / \mu \mathrm{L}$ in 2 protocols (water deprivation and sodium depletion) and ATP was administered at the dose of 300 $\mathrm{nmol} / \mu \mathrm{L}$ in the other protocols. PPADS and DPCPX were administered into the LV at the dose of $25 \mathrm{nmol} / \mu \mathrm{L}$ only in water-deprived rats. ANG II and carbachol were administered into the $L V$ at the doses of $50 \mathrm{ng} / \mu \mathrm{L}$ and $4 \mathrm{nmol} / \mu \mathrm{L}$, respectively. Doses of ATP, PPADS, and DPCPX were chosen on the basis of pilot experiments. Doses of ANG II and carbachol were based on a previous study (28).

Furosemide (Sigma) was administered subcutaneously (sc) at $20 \mathrm{mg} / \mathrm{kg}$ body weight and was dissolved in alkaline saline ( $\mathrm{pH}$ adjusted to 9.0 with $\mathrm{NaOH}$ ), as described previously (29).

\section{Histology}

At the end of the experiments, the animals received an injection of $1 \mu \mathrm{L} 2 \%$ Evans blue solution into the LV. They were then deeply anesthetized with an intraperitoneal 
injection of sodium thiopental $(80 \mathrm{mg} / \mathrm{kg}$ body weight; Cristália) and perfused transcardially with saline followed by $10 \%$ formalin. The brains were removed, fixed in $10 \%$ formalin, frozen, cut into $50-\mu \mathrm{m}$ sections, stained with Giemsa, and analyzed by light microscopy to confirm that the injection sites were in the LV. Only data from animals in which injections reached the LV were considered in the analysis.

\section{Statistical analysis}

Data are reported as means \pm SEM. Two-way repeated-measures analysis of variance (ANOVA) or oneway ANOVA followed by the Newman-Keuls test was used for group comparison. The level of significance was set at $\mathrm{P}<0.05$ in all tests.

\section{Experimental protocols tested}

a) Water deprivation-induced water intake. Water and $1.8 \% \mathrm{NaCl}$ were removed from the cage and only food remained available for $24 \mathrm{~h}$. After this period, ATP (100, 200 , or $300 \mathrm{nmol} / \mu \mathrm{L}$ ) or vehicle (saline) was injected into the LV $10 \mathrm{~min}$ before the burettes containing water and $1.8 \% \mathrm{NaCl}$ became available to the animals. Cumulative water and $1.8 \% \mathrm{NaCl}$ intake was measured for the next $2 \mathrm{~h}$ (at $0,15,30,45,60$, and $120 \mathrm{~min}$ ) in the absence of food. In another group of rats, PPADS or DPCPX (P2 and P1 purinergic antagonists, respectively, $25 \mathrm{nmol} / \mu \mathrm{L}$ ) or vehicle was injected into the LV 10 min before ATP (300 $\mathrm{nmol} / \mu \mathrm{L}$ ) or saline. Each rat was submitted to four experimental tests. In each test, the group of rats was divided into two subgroups and each half of the group received one of the treatments. The sequence of the treatments in different tests was randomized and at the end of four tests all animals had received all treatments. Water, $1.8 \% \mathrm{NaCl}$ and standard food were returned to the animals at the end of the intake test. A recovery period of at least 3 days was allowed between tests.

b) Water intake induced by intragastric load of $12 \%$ $\mathrm{NaCl}$. Another group of animals was trained daily for at least 3 days to receive the intragastric load (gavage). The training was performed once a day and consisted of carefully holding the animal and injecting $2 \mathrm{~mL} 0.9 \% \mathrm{NaCl}$ through PE-200 polyethylene tubing from a 5-mL syringe into the stomach. On the day of the experiment, food, water and $1.8 \% \mathrm{NaCl}$ were removed from the cages, and the animals received an intragastric load (gavage) of $12 \%$ (2 M) $\mathrm{NaCl}$ or $0.9 \% \mathrm{NaCl}(2 \mathrm{~mL} /$ rat $)$. The intragastric load of $12 \% \mathrm{NaCl}$ produces a $4 \%$ elevation of both plasma osmolality and sodium concentration, inducing cell dehydration and thus water intake (23). Concurrent reduction of plasma renin activity and no alteration in plasma volume indicate that the procedure does not induce extracellular dehydration (23). Fifty minutes after gavage with $12 \% \mathrm{NaCl}$ or $0.9 \%$ $\mathrm{NaCl}$ (control), ATP (300 nmol/ $\mu \mathrm{L}$ ) or vehicle (saline) was injected $i c v$. Half the group received ATP and the other half received vehicle (saline) into the $L V$. Ten minutes after ATP, the animals had access to both water and $1.8 \% \mathrm{NaCl}$ in $0.1-\mathrm{mL}$ graduated glass burettes. Cumulative water and $1.8 \% \mathrm{NaCl}$ intake was recorded at $15,30,45,60,90$, and $120 \mathrm{~min}$. This procedure was repeated in a counterbalanced design in a second experimental session performed 2 days later.

c) Acute furosemide-induced water intake. Food, 1.8\% $\mathrm{NaCl}$ and water were removed from the cages and the rats were injected $s c$ with the diuretic/natriuretic furosemide (20 mg/kg body weight). This dose of furosemide induces a rapid and maximum loss of water and electrolytes, including sodium and potassium, within $1 \mathrm{~h}(24,25)$. Fifty minutes after the $s c$ injection of furosemide, ATP (300 $\mathrm{nmol} / \mu \mathrm{L}$ ) or vehicle (saline) was injected $i c v$. Ten minutes later, water and $1.8 \% \mathrm{NaCl}$ were offered to the animals in 0.1-mL graduated glass burettes fitted with stainless steel spouts. Cumulative water and $1.8 \% \mathrm{NaCl}$ intake was recorded at 15, 30, 45, 60, 90, and 120 min after the access to these fluids. At the end of the test, water, food and $1.8 \%$ $\mathrm{NaCl}$ were made available to the animals until the next test. This procedure was repeated in a counterbalanced design in a second experimental test performed 2 days later.

d) Central ANG II- and carbachol-induced water intake. In another group of normohydrated rats, water intake was induced by icv injection of ANG II (50 ng/ $\mu \mathrm{L})$ or carbachol $(4 \mathrm{nmol} / \mu \mathrm{L})$. Cumulative water and $1.8 \% \mathrm{NaCl}$ intake was recorded for $2 \mathrm{~h}$ (at 15, 30, 45, 60, 90, and $120 \mathrm{~min}$ ) immediately after the injection of ANG II or carbachol. ATP (300 $\mathrm{nmol} / \mu \mathrm{L}$ ) or vehicle (saline) was injected icv $10 \mathrm{~min}$ before the injection of ANG II or carbachol. The same procedure was repeated in a counterbalanced design in a second experimental test performed 2 days later.

e) Sodium depletion-induced $1.8 \% \mathrm{NaCl}$ intake. The rat's cage was rinsed with water to eliminate any environmental sodium and sodium depletion was induced by an sc injection of furosemide ( $20 \mathrm{mg} / \mathrm{kg}$ body weight) followed by animal access to only water and sodium-deficient food (powdered corn meal; $0.001 \%$ sodium and $0.33 \%$ potassium) for $24 \mathrm{~h}$. Then, food was removed and the injections of ATP $(100,200$, and $300 \mathrm{nmol} / \mu \mathrm{L})$ or vehicle (saline) into the LV were performed. Ten minutes after the injection of ATP, water and $1.8 \% \mathrm{NaCl}$ were provided to the animals in $0.1-\mathrm{mL}$ graduated glass burettes fitted with stainless steel spouts. Cumulative water and $1.8 \% \mathrm{NaCl}$ intakes were measured at 15, 30, 45, 60, 90, and $120 \mathrm{~min}$. In each test, the group of rats was divided into two equal subgroups, 
each receiving one of the treatments. The sequence of the treatments in different tests was randomized and at the end of four tests all animals had received all treatments. Each rat was submitted to four experimental depletion tests. A recovery period of at least 3 days was allowed between tests. Treatment with furosemide induces a 1.5 to $2.0 \mathrm{mEq}$ loss of sodium and consistent intake of hypertonic sodium solutions (24,30-32).

f) Food deprivation-induced food intake. Another group of rats was submitted to $24 \mathrm{~h}$ of food deprivation with water available. Food deprivation started at 8:00 am on the day before the test. Ten minutes before the beginning of the meal test, the animals received an icvinjection of ATP (300 $\mathrm{nmol} / \mu \mathrm{L}$ ) or vehicle (saline). Food intake was measured at $15,30,60,90$, and 120 min from the beginning of the test.
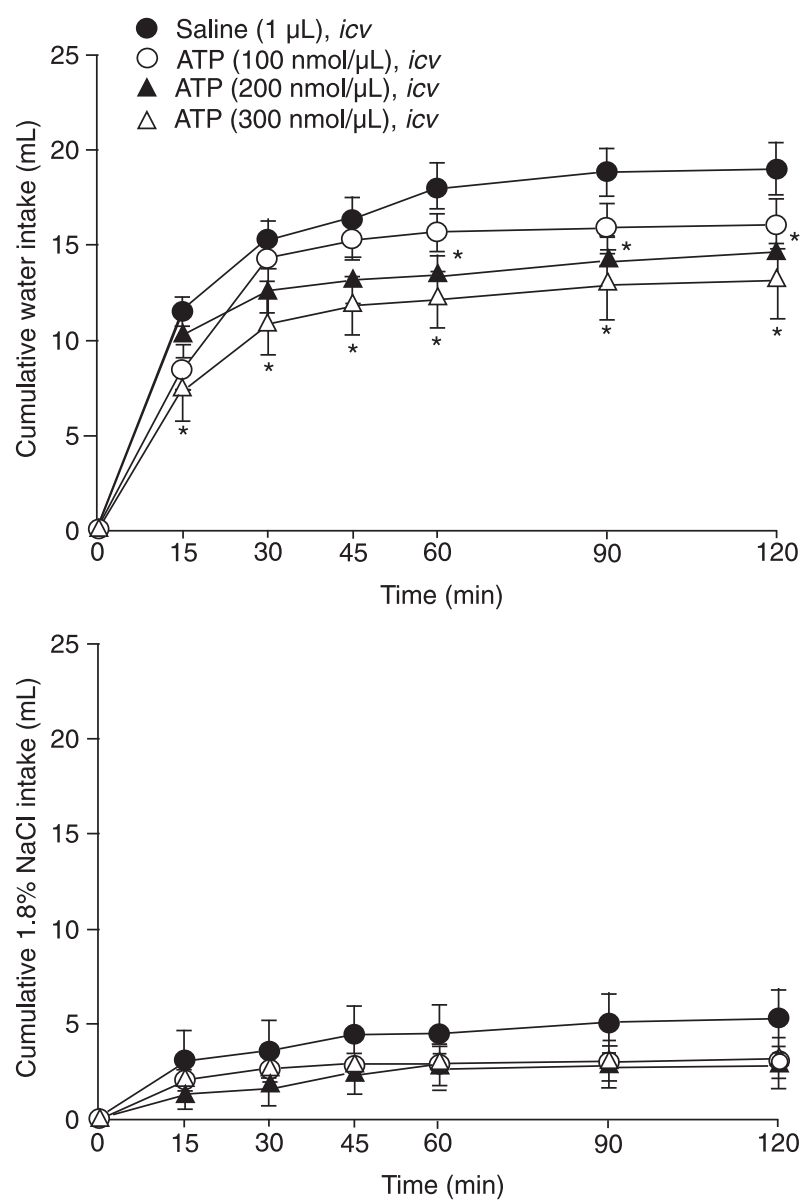

Figure 1. Cumulative water (upper panel) and $1.8 \% \mathrm{NaCl}$ intake (lower panel) of 24-h water-deprived rats treated with icv injections of ATP $(100,200$, and $300 \mathrm{nmol} / \mu \mathrm{L})$ or saline. Data are reported as means \pm SEM for 9 rats in each group. ${ }^{*} P<0.05$ compared to saline icv (one-way ANOVA and Newman-Keuls test).
The same procedure was repeated in a counterbalanced design in a second experimental test performed 2 days later. The measurement of food intake was accurate to $0.1 \mathrm{~g}$.

\section{Results}

Effects of icv injection of ATP alone or combined with icv PPADS or DPCPX on water and $1.8 \% \mathrm{NaCl}$ intake in water-deprived rats

Icv injection of ATP (200 and $300 \mathrm{nmol} / \mu \mathrm{L})$ reduced water intake in water-deprived rats in a dose-dependent manner during the entire 2-h test $(14.6 \pm 1.5$ and $13.1 \pm 1.9$ $\mathrm{mL} / 2 \mathrm{~h}$, respectively, vs saline: $19.0 \pm 1.4 \mathrm{~mL} / 2 \mathrm{~h}, \mathrm{~N}=9 ; \mathrm{P}$ $<0.05$, Figure 1 , upper panel). The low dose of ATP (100 $\mathrm{nmol} / \mu \mathrm{L})$ had no effect on water intake $(16.1 \pm 1.4 \mathrm{vs}$ saline: $19.0 \pm 1.4 \mathrm{~mL} / 2 \mathrm{~h}$, Figure 1, upper panel). None of the doses of ATP tested (100, 200 and $300 \mathrm{nmol} / \mu \mathrm{L})$ had an effect on $1.8 \% \mathrm{NaCl}$ intake in water-deprived rats $(3.0 \pm$ $0.5,2.71 \pm 1.1$ and $3.2 \pm 1.1 \mathrm{~mL} / 2 \mathrm{~h}$, respectively, vs saline: $5.3 \pm 1.5 \mathrm{~mL} / 2 \mathrm{~h}$, Figure 1, lower panel).

Pre-treatment with icv PPADS $(25 \mathrm{nmol} / \mu \mathrm{L})$ reduced the inhibitory effect of icv ATP $(300 \mathrm{nmol} / \mu \mathrm{L})$ on water intake in water-deprived rats at 15 and 30 min into the test (9.4 \pm 1.2 and $14.4 \pm 0.9 \mathrm{~mL} / 15$ and $30 \mathrm{~min}$, respectively, vs saline + ATP: $4.4 \pm 0.8$ and $9.1 \pm 1.2 \mathrm{~mL} / 15$ and $30 \mathrm{~min}$, respectively, $\mathrm{N}=10 ; \mathrm{P}<0.05$, Figure 2). PPADS (25 nmol/ $\mu \mathrm{L}$ ) alone produced no significant change in the water intake induced by water deprivation (Figure 2).

Pre-treatment with icv DPCPX $(25 \mathrm{nmol} / \mu \mathrm{L})$ produced no significant change on the antidipsogenic action of ATP (Figure 3).

Effects of icv injection of ATP on water and $1.8 \% \mathrm{NaCl}$ intake in rats treated with an intragastric load of $12 \%$ $\mathrm{NaCl}$

In rats treated with an intragastric load of $12 \% \mathrm{NaCl}(2$ $\mathrm{mL} / \mathrm{rat}), i c v$ injection of ATP $(300 \mathrm{nmol} / \mu \mathrm{L})$ reduced water intake $(5.6 \pm 0.9$ vs saline: $10.3 \pm 1.4 \mathrm{~mL} / 2 \mathrm{~h}, \mathrm{~N}=7 ; \mathrm{P}<$ 0.05 , Figure 4 , upper panel), without changing $1.8 \% \mathrm{NaCl}$ intake $(1.0 \pm 0.5$ vs saline: $0.9 \pm 0.5 \mathrm{~mL} / 2 \mathrm{~h}$, Figure 4 , lower panel).

When rats were treated with an intragastric load of $0.9 \% \mathrm{NaCl}(2 \mathrm{~mL} / \mathrm{rat})$, icv injection of ATP (300 nmol/ $\mu \mathrm{L})$ did not change water intake $(0.4 \pm 0.2$ vs saline: $1.7 \pm 0.7$ $\mathrm{mL} / 2 \mathrm{~h}, \mathrm{~N}=7)$ or $1.8 \% \mathrm{NaCl}$ intake $(0.5 \pm 0.1$ vs saline: 0.7 $\pm 0.5 \mathrm{~mL} / 2 \mathrm{~h}$ ) (data not shown).

Effects of icv injection of ATP on water and $1.8 \% \mathrm{NaCl}$ intake in rats acutely treated with furosemide

In rats acutely treated with $s c$ furosemide $(20 \mathrm{mg} / \mathrm{kg}$ body weight), icv injection of ATP (300 nmol/ $\mu \mathrm{L})$ reduced 
water intake during the first $15 \mathrm{~min}$ of the experimental period $(0.5 \pm 0.2$ vs saline: $2.3 \pm 0.6 \mathrm{~mL} / 15 \mathrm{~min}, \mathrm{~N}=8 ; \mathrm{P}<$ 0.05 , Figure 5 , upper panel), without changing $1.8 \% \mathrm{NaCl}$ intake at any time during the test (Figure 5, lower panel).

\section{Effects of icv injection of ATP on ANG II- or carbachol-} induced water intake in rats

IcV injection of ATP $(300 \mathrm{nmol} / \mu \mathrm{L})$ reduced water intake induced by icv ANG II (50 ng/ $\mu \mathrm{L})$ throughout the test

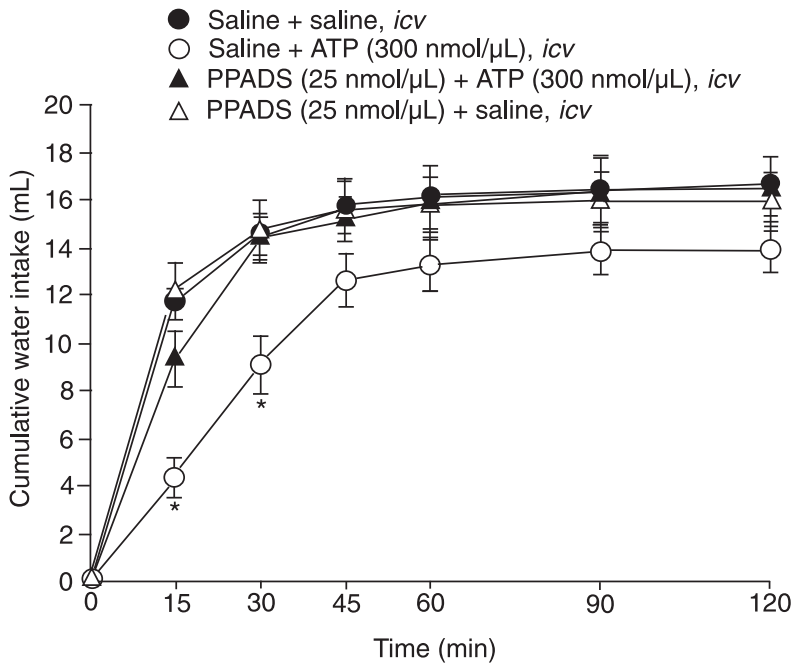

Figure 2. Cumulative water intake of 24-h water-deprived rats treated with icv injections of PPADS (25 nmol/ $\mu \mathrm{L})$ or saline combined with icv ATP $(300 \mathrm{nmol} / \mu \mathrm{L})$ or saline. Data are reported as means \pm SEM for 10 rats in each group. PPADS = pyridoxalphosphate-6-azophenyl-2',4'-disulfonic acid. * $P<0.05$ compared to saline + saline icv (two-way ANOVA and NewmanKeuls test).

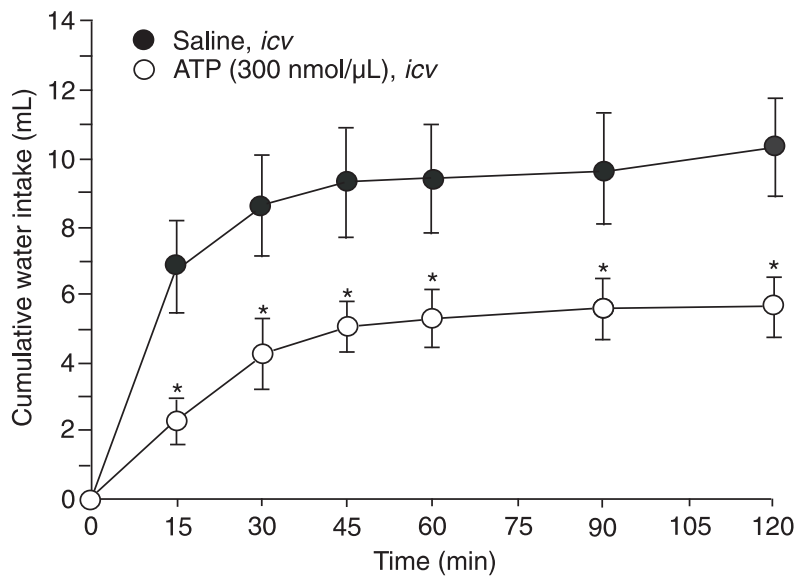

(2.2 \pm 0.8 vs saline: $10.4 \pm 2.0 \mathrm{~mL} / 2 \mathrm{~h}, \mathrm{~N}=8 ; \mathrm{P}<0.05$, Figure 6, upper panel), without changing $1.8 \% \mathrm{NaCl}$ intake $(3.4 \pm 2.9$ vs saline: $4.2 \pm 1.5 \mathrm{~mL} / 2 \mathrm{~h}$, Figure 6 , lower panel).

Icv injection of ATP (300 nmol/ $\mu \mathrm{L})$ had no effect on icv carbachol $(4 \mathrm{nmol} / \mu \mathrm{L})$-induced water intake $(6.0 \pm 1.6 \mathrm{vs}$ saline: $7.4 \pm 1.5 \mathrm{~mL} / 2 \mathrm{~h}, \mathrm{~N}=8)$, or on $1.8 \% \mathrm{NaCl}$ intake $(2.2$ \pm 0.7 vs saline: $2.0 \pm 0.7 \mathrm{~mL} / 2 \mathrm{~h}$ ) (data not shown).

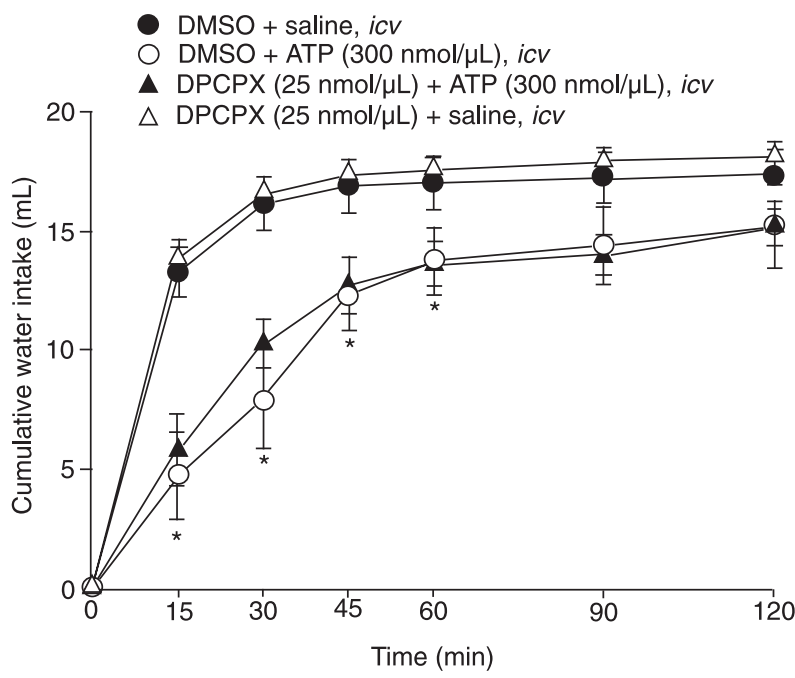

Figure 3. Cumulative water intake of 24-h water-deprived rats treated with icv injections of DPCPX $(25 \mathrm{nmol} / \mu \mathrm{L})$ or DMSO (vehicle) combined with icv ATP $(300 \mathrm{nmol} / \mu \mathrm{L})$ or saline. Data are reported as means \pm SEM for 8 rats in each group. DPCPX $=$ 1,3-dipropyl-8-cyclopentylxanthine; DMSO = dimethyl sulfoxide. ${ }^{*} \mathrm{P}<0.05$ compared to DMSO + saline icv (two-way ANOVA and Newman-Keuls test)

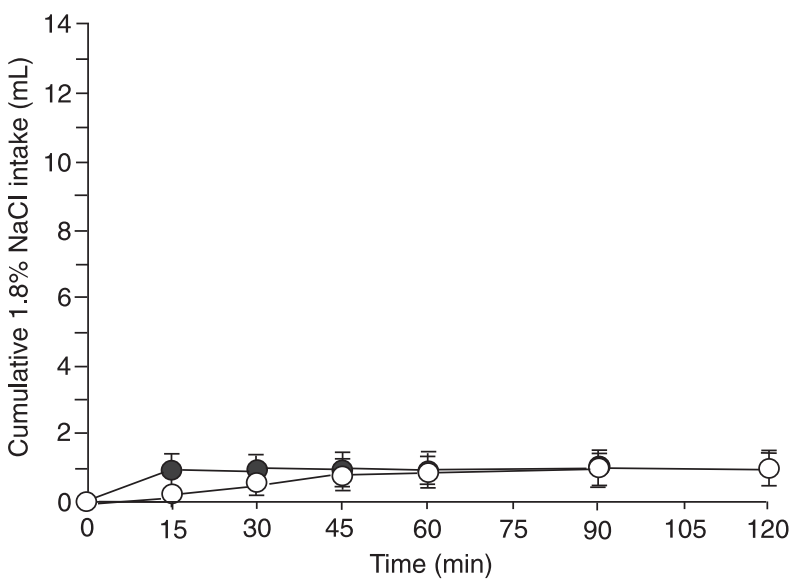

Figure 4. Cumulative water (left panel) and $1.8 \% \mathrm{NaCl}$ intake (right panel) induced by an intragastric load of $12 \% \mathrm{NaCl}(2 \mathrm{~mL})$ in rats treated with icv injections of ATP $(300 \mathrm{nmol} / \mu \mathrm{L})$ or saline. Data are reported as means $\pm \mathrm{SEM}$ for 7 rats in each group. ${ }^{*} \mathrm{P}<0.05$ compared to saline icv (one-way ANOVA and Newman-Keuls test). 

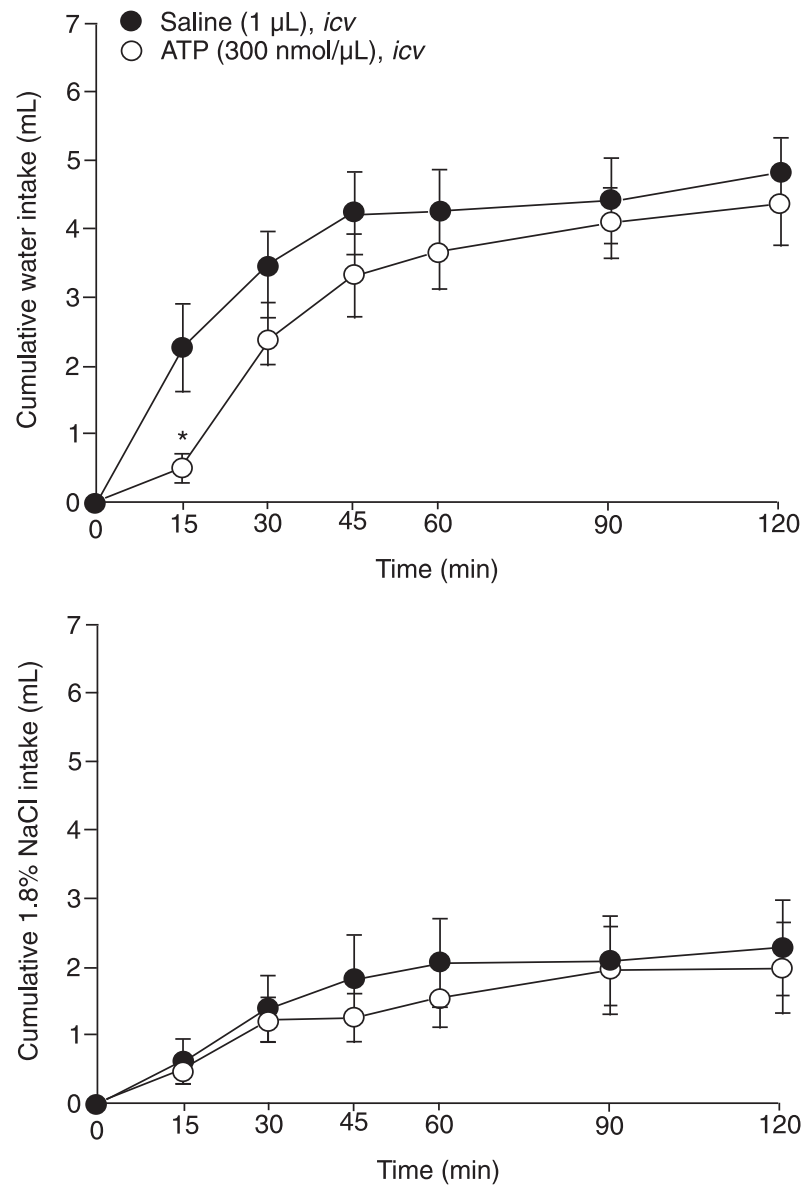

Figure 5. Cumulative water (upper panel) and 1.8\% $\mathrm{NaCl}$ intake (lower panel) induced by acute treatment with sc furosemide (20 $\mathrm{mg} / \mathrm{kg}$ body weight) in rats treated with icv injections of ATP (300 $\mathrm{nmol} / \mu \mathrm{L}$ ) or saline. Data are reported as means \pm SEM for 8 rats in each group. ${ }^{*} \mathrm{P}<0.05$ compared to saline icv (one-way ANOVA and Newman-Keuls test).

Effects of icv injection of ATP on sodium depletioninduced $1.8 \% \mathrm{NaCl}$ and water intake

None of the ATP doses $(100,200$, and $300 \mathrm{nmol} / \mu \mathrm{L})$ had any effect on sodium depletion-induced $1.8 \% \mathrm{NaCl}$ intake $(19.8 \pm 1.4,17.0 \pm 2.2,17.5 \pm 1.2 \mathrm{~mL} / 2 \mathrm{~h}$, respectively, vs saline: $16.4 \pm 2.4 \mathrm{~mL} / 2 \mathrm{~h}, \mathrm{~N}=7$ ) or water intake $(0.6 \pm 0.2,1.1 \pm 0.3$ and $2.5 \pm 0.8 \mathrm{~mL} / 2 \mathrm{~h}$, respectively, vs saline: $1.5 \pm 0.4 \mathrm{~mL} / 2 \mathrm{~h}, \mathrm{~N}=7$ ).

Effects of icv injection of ATP on food intake in fooddeprived rats

I $c v$ injection of ATP $(300 \mathrm{nmol} / \mu \mathrm{L})$ did not change food intake induced by $24 \mathrm{~h}$ of food deprivation throughout the test $(7.7 \pm 0.6$ vs saline: $8.2 \pm 0.7 \mathrm{~g} / 2 \mathrm{~h}, \mathrm{~N}=11)$.
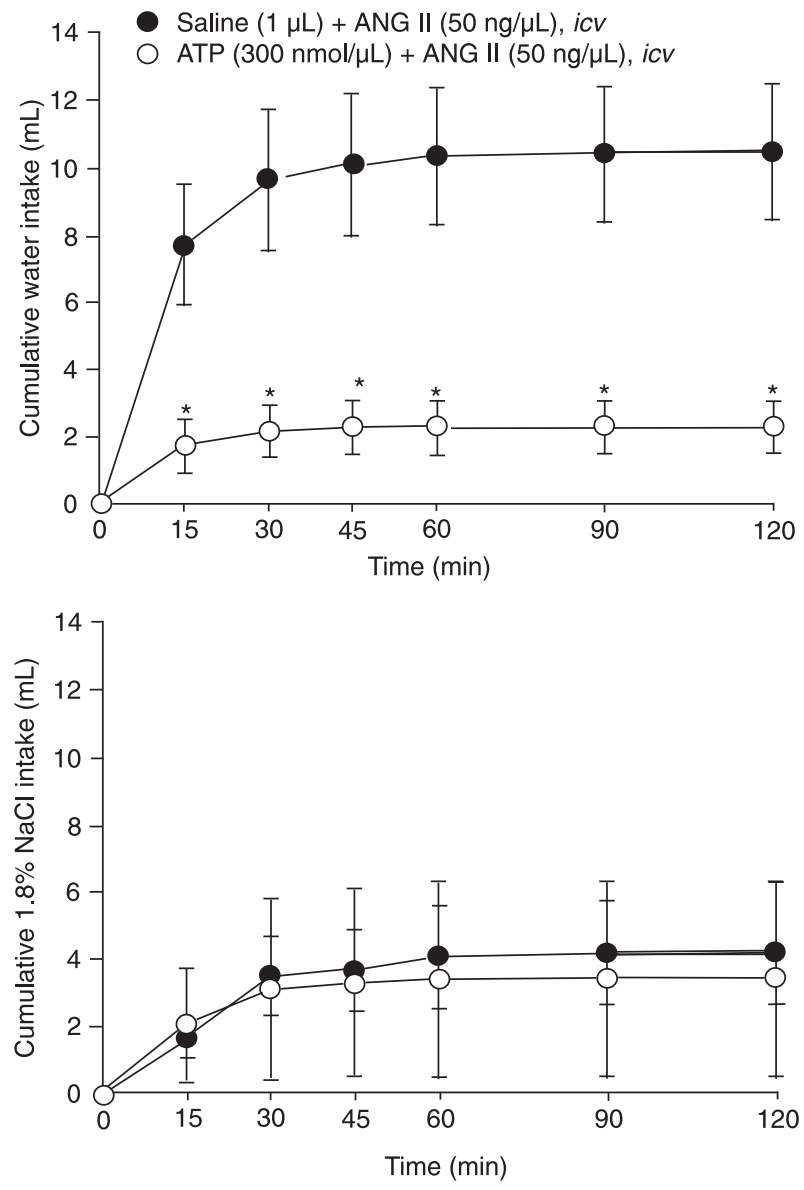

Figure 6. Cumulative water (upper panel) and $1.8 \% \mathrm{NaCl}$ intake (lower panel) induced by icv injection of ANG II $(50 \mathrm{ng} / \mu \mathrm{L})$ in rats previously treated with icv injection of ATP $(300 \mathrm{nmol} / \mu \mathrm{L})$ or saline. Data are reported as means \pm SEM for 8 rats in each group. ${ }^{*} \mathrm{P}<0.05$ compared to saline + ANG II icv (one-way ANOVA and Newman-Keuls test).

\section{Discussion}

Terrestrial animals have evolved several complex mechanisms to ensure constancy of body fluid. The brain receives and integrates different types of hydration-related input, and the result of this integrative process determines the probability for the animal to ingest water and/or sodium (for a review, see Ref. 33).

The present results show that central injections of ATP experimentally inhibit induced water intake in rats. IcV injection of ATP reduced water intake induced by intracellular dehydration (intragastric load of $12 \% \mathrm{NaCl}$ ), extracellular dehydration (acute sc furosemide), a mix of intra- and extracellular dehydration (water deprivation), and also icv 
ANG II that mimics extracellular dehydration. Therefore, the activation of central purinergic receptors with ATP inhibits dipsogenic responses to different stimuli, except water intake produced by central cholinergic activation or the low water intake in a protocol more related to sodium ingestion (sodium depletion). Central injection of ATP did not affect the ingestion of hypertonic $\mathrm{NaCl}$ or food, suggesting that the inhibitory effect of ATP on water intake is not the result of nonspecific inhibition of all ingestive behaviors.

The present study provides the first evidence for the involvement of central purinergic mechanisms in the control of fluid and electrolyte balance. However, because ATP in the CNS can be quickly converted to adenosine by the enzymatic action of adenosine triphosphatase and ecto-5'-nucleotidase $(3,4)$, the antidipsogenic responses described in the present study might be due to ATP acting on central purinergic $\mathrm{P} 2$ receptors (classified as $\mathrm{P} 2 \mathrm{X}$ and $\mathrm{P} 2 \mathrm{Y}$ ) or adenosine acting on central purinergic $\mathrm{P} 1$ receptors (classified as A1, A2 and A3). To identify the receptor involved in the antidipsogenic response to ATP, we tested the effects of icv ATP after pretreatment with PPADS (a purinergic $\mathrm{P} 2$ receptor antagonist) or DPCPX (a purinergic $\mathrm{P} 1$ receptor antagonist more specific for adenosine $\mathrm{A} 1$ receptors; 34) on water intake induced by $24 \mathrm{~h}$ of water deprivation. PPADS, but not DPCPX, abolished the antidipsogenic effect of ATP, suggesting that the inhibitory effect of ATP on water intake is due to central purinergic P2 receptor activation. It is important to emphasize that our results suggest that the antidipsogenic action of ATP is not due to $A 1$ activation, but do not rule out a possible action of ATP via adenosine A2 or A3 receptors. Thus, further studies are necessary to determine if other kinds of adenosine receptors are involved in the inhibitory effects of central ATP on water intake.

ANG II acting centrally is the main facilitatory mechanism activated by extracellular dehydration (21) to induce water intake and central cholinergic mechanisms are suggested to play a role in intracellular dehydration-induced dipsogenic responses $(26,27)$. Central ATP reduced icv ANG II-induced water intake and all other models of extracellular dehydration-induced water intake tested, clearly suggesting that central purinergic mechanisms inhibit water intake induced by extracellular dehydration. Central ATP also reduced water intake induced by intracellular dehydration (intragastric load of $12 \% \mathrm{NaCl}$ ), but failed to reduce carbachol-induced water intake. The intragastric load of $12 \% \mathrm{NaCl}$ induces intracellular dehydration, increasing plasma osmolality and sodium concentration and reducing plasma renin activity (23). Therefore, an intragastric load of $12 \% \mathrm{NaCl}$ is a typical model that induces intracellular dehydration-induced water intake, suggesting that central ATP also reduces water intake induced by this experimental condition. The reasons why ATP did not affect carbachol-induced water intake are not clear. Perhaps central cholinergic activation-induced water intake does not totally mimics intracellular dehydration-induced water intake as suggested by Levitt and Fisher (35). Or, although central cholinergic mechanisms are part of the mechanisms activated by intracellular dehydration to induce thirst, ATP might act in one of the first steps (or synapse) of the pathway before the activation of the cholinergic mechanisms.

In addition to the absence of any effect of ATP on carbachol-induced water intake, the inhibitory effects of ATP on water intake in other protocols tested were also variable. Central ATP produced a strong reduction of water intake induced by intragastric load of $12 \% \mathrm{NaCl}$ (intracellular dehydration-induced thirst) or icv ANG II (extracellular dehydration-induced thirst). However, icv ATP produced only a partial reduction of water deprivation-induced water intake and weakly reduced water intake only at 15 min into the test in rats acutely treated with furosemide. The different effects of ATP in different protocols of water intake may be the result of the different interactions between facilitatory and inhibitory mechanisms activated in each situation. For example, rats acutely treated with furosemide have increased renin activity together with hypovolemia $(24,25)$ that is an additional signal to increase water intake, while central injection of ANG II induces water intake in spite of the pressor response that is an inhibitory signal for water intake.

The effects of ATP on water intake are very similar to those produced by treatment with moxonidine and clonidine (alpha ${ }_{2}$-adrenergic/imidazoline agonists), that are typical antidipsogenic drugs (28,36-40). Taken together, our data and those of the literature suggest that activation of central alpha ${ }_{2}$-adrenergic receptors $(28,36-40)$ and central purinergic receptors with ATP (present data) inhibits the excitatory mechanisms related to the control of water intake. The effects of activation of central alpha ${ }_{2}$-adrenergic and central $\mathrm{P} 2$ purinergic receptors on water intake are not the result of a nonspecific inhibition of all ingestive behaviors because food intake was not affected by icv injections of norepinephrine (40) or ATP (present data). Because ATP may act as a co-transmitter with different neurotransmitters (17), including norepinephrine, or that ATP may also release norepinephrine (17), an interaction may exist between ATP and norepinephrine in the forebrain to control water intake, which deserves further investigation.

The present results suggest that inhibitory purinergic 
mechanisms in the forebrain may contribute to the control of water intake. However, further studies are necessary to demonstrate which areas of the brain are involved in the effects of ATP on water intake. Therefore, a complete evaluation of the role of central purinergic mechanisms in the control of water intake may make an important contribution to the understanding of the complex neural network that maintains fluid balance.

\section{References}

1. Burnstock G. Purinergic nerves. Pharmacol Rev 1972; 24: 509-581.

2. Ralevic V, Burnstock G. Receptors for purines and pyrimidines. Pharmacol Rev 1998; 50: 413-492.

3. St Lambert JH, Thomas T, Burnstock G, Spyer KM. A source of adenosine involved in cardiovascular responses to defense area stimulation. Am J Physiol 1997; 272: R195R200.

4. Burger RM, Lowenstein JM. 5'-Nucleotidase from smooth muscle of small intestine and from brain. Inhibition of nucleotides. Biochemistry 1975; 14: 2362-2366.

5. Ergene E, Dunbar JC, O'Leary DS, Barraco RA. Activation of $\mathrm{P} 2$-purinoceptors in the nucleus tractus solitarius mediate depressor responses. Neurosci Lett 1994; 174: 188192.

6. Barraco RA, O'Leary DS, Ergene E, Scislo TJ. Activation of purinergic receptor subtypes in the nucleus tractus solitarius elicits specific regional vascular response patterns. $J$ Auton Nerv Syst 1996; 59: 113-124.

7. Phillis JW, Scislo TJ, O'Leary DS. Purines and the nucleus tractus solitarius: effects on cardiovascular and respiratory function. Clin Exp Pharmacol Physiol 1997; 24: 738-742.

8. Scislo TJ, Augustyniak RA, Barraco RA, Woodbury DJ, O'Leary DS. Activation of P2x-purinoceptors in the nucleus tractus solitarius elicits differential inhibition of lumbar and renal sympathetic nerve activity. J Auton Nerv Syst 1997; 62: $103-110$.

9. Scislo TJ, Ergene E, O'Leary DS. Impaired arterial baroreflex regulation of heart rate after blockade of P2-purinoceptors in the nucleus tractus solitarius. Brain Res Bull 1998; 47: 63-67.

10. Gourine AV, Melenchuk EV, Poputnikov DM, Gourine VN, Spyer KM. Involvement of purinergic signalling in central mechanisms of body temperature regulation in rats. $\mathrm{Br} \mathrm{J}$ Pharmacol 2002; 135: 2047-2055.

11. Gourine AV, Atkinson L, Deuchars J, Spyer KM. Purinergic signalling in the medullary mechanisms of respiratory control in the rat: respiratory neurones express the $\mathrm{P} 2 \mathrm{X} 2$ receptor subunit. J Physiol 2003; 552: 197-211.

12. Gourine AV, Dale N, Gourine VN, Spyer KM. Fever in systemic inflammation: roles of purines. Front Biosci 2004; 9: 1011-1022.

13. Gourine AV, Llaudet E, Dale N, Spyer KM. ATP is a mediator of chemosensory transduction in the central nervous

\section{Acknowledgments}

The authors thank Professor Laurival A. De Luca Jr. for his suggestions in the dehydration protocols, Professor Gus H. Schoorlemmer (Physiology Department, Universidade Federal de São Paulo, São Paulo, SP, Brazil) for his help in the revision of the manuscript, Silvana Malavolta for secretarial assistance, Silvia Foglia, Silas P. Barbosa and Reginaldo C. Queiroz for technical assistance, and Ana Vitor Oliveira for animal care.

14. de Paula PM, Antunes VR, Bonagamba LG, Machado BH. Cardiovascular responses to microinjection of ATP into the nucleus tractus solitarii of awake rats. Am J Physiol Regul Integr Comp Physiol 2004; 287: R1164-R1171.

15. Antunes VR, Braga VA, Machado BH. Autonomic and respiratory responses to microinjection of ATP into the intermediate or caudal nucleus tractus solitarius in the working heartbrainstem preparation of the rat. Clin Exp Pharmacol Physiol 2005; 32: 467-472.

16. Antunes VR, Bonagamba LG, Machado BH. Hemodynamic and respiratory responses to microinjection of ATP into the intermediate and caudal NTS of awake rats. Brain Res 2005; 1032: 85-93.

17. Burnstock G. Physiology and pathophysiology of purinergic neurotransmission. Physiol Rev 2007; 87: 659-797.

18. Yao ST, Barden JA, Finkelstein DI, Bennett MR, Lawrence AJ. Comparative study on the distribution patterns of $\mathrm{P} 2 \mathrm{X}(1)-\mathrm{P} 2 \mathrm{X}(6)$ receptor immunoreactivity in the brainstem of the rat and the common marmoset (Callithrix jacchus): association with catecholamine cell groups. J Comp Neurol 2000; 427: 485-507.

19. Atkinson L, Batten TF, Deuchars J. P2X(2) receptor immunoreactivity in the dorsal vagal complex and area postrema of the rat. Neuroscience 2000; 99: 683-696.

20. Florenzano F, Carrive P, Viscomi MT, Ferrari F, Latini L, Conversi $\mathrm{D}$, et al. Cortical and subcortical distribution of ionotropic purinergic receptor subunit type $1(\mathrm{P} 2 \mathrm{X}(1) \mathrm{R}) \mathrm{im}$ munoreactive neurons in the rat forebrain. Neuroscience 2008; 151: 791-801.

21. Fitzsimons JT. Thirst. Physiol Rev 1972; 52: 468-561.

22. Hoffman WE, Ganten U, Phillips MI, Schmid PG, Schelling $P$, Ganten D. Inhibition of drinking in water-deprived rats by combined central angiotensin II and cholinergic receptor blockade. Am J Physiol 1978; 234: F41-F47.

23. Pereira DT, Vendramini RC, David RB, Nozaki PN, Menani JV, De Luca LA Jr. Isotonic $\mathrm{NaCl}$ intake by cell-dehydrated rats. Physiol Behav 2002; 76: 501-505.

24. Jalowiec JE. Sodium appetite elicited by furosemide: effects of differential dietary maintenance. Behav Biol 1974; 10: 313-327.

25. Pereira DT, David RB, Vendramini RC, Menani JV, De Luca LA Jr. Potassium intake during cell dehydration. Physiol Behav 2005; 85: 99-106. 
26. Block ML, Fisher AE. Anticholinergic central blockade of salt-aroused and deprivation-induced drinking. Physiol Behav 1970; 5: 525-527.

27. Block ML, Fisher AE. Cholinergic and dopaminergic blocking agents modulate water intake elicited by deprivation, hypovolemia, hypertomicity and isoproterenol. Pharmacol Biochem Behav 1975; 3: 251-262.

28. Menani JV, Sato MA, Haikel L, Vieira AA, de Andrade CA, da Silva DC, et al. Central moxonidine on water and $\mathrm{NaCl}$ intake. Brain Res Bull 1999; 49: 273-279.

29. Yada MM, de Paula PM, Menani JV, Renzi A, Camargo LA, Saad WA, et al. Receptor-mediated effects of clonidine on need-induced $3 \% \mathrm{NaCl}$ and water intake. Brain Res Bull 1997; 42: 205-209.

30. De Luca LA Jr, Galaverna O, Schulkin J, Yao SZ, Epstein AN. The anteroventral wall of the third ventricle and the angiotensinergic component of need-induced sodium intake in the rat. Brain Res Bull 1992; 28: 73-87.

31. Sakai RR, Frankmann SP, Fine WB, Epstein AN. Prior episodes of sodium depletion increase the need-free sodium intake of the rat. Behav Neurosci 1989; 103: 186-192.

32. Rowland NE, Fregly MJ. Repletion of acute sodium deficit in rats drinking either low or high concentrations of sodium chloride solution. Am J Physiol 1992; 262: R419-R425

33. De Luca LA Jr, Vivas L, Menani JV. Controle neuroendócrino da ingestão de água e sódio. In: Antunes-Rodrigues $\mathrm{J}$, Moreira AC, Castro M, Elias LLK (Editors), Neuroendocrinologia Básica e Aplicada. 1a. edn. Rio de Janeiro: Guanabara
Koogan; 2004. p 116-134.

34. Katsushima T, Nieves L, Wells JN. Structure-activity relationships of 8-cycloalkyl-1,3-dipropylxanthines as antagonists of adenosine receptors. J Med Chem 1990; 33: 19061910.

35. Levitt RA, Fisher AE. Failure of central anticholinergic brain stimulation to block natural thirst. Physiol Behav 1967; 2: 425-428.

36. Fregly MJ, Kelleher DL, Greenleaf JE. Antidipsogenic effect of clonidine on isoproterenol induced water intake. Appetite J 1980; 1: 279-289.

37. Fregly MJ, Kelleher DL, Greenleaf JE. Antidipsogenic effect of clonidine on angiotensin II, hypertonic saline, pilocarpine and dehydration-induced water intake. Brain Res Bull 1981; 7: 661-664

38. Callera JC, Camargo LA, de Luca Junior LA, Menani JV, Renzi A, Saad WA. Clonidine and phenylephrine injected into the lateral preoptic area reduce water intake in dehydrated rats. Pharmacol Biochem Behav 1993; 46: 39-43.

39. Sugawara AM, Miguel TT, Pereira DT, Menani JV, De Luca LA Jr. Effects of central imidazolinergic and alpha2-adrenergic activation on water intake. Braz J Med Biol Res 2001; 34: 1185-1190.

40. Sugawara AM, Miguel TT, de Oliveira LB, Menani JV, de Luca Junior LA. Noradrenaline and mixed alpha 2-adrenoceptor/imidazoline-receptor ligands: effects on sodium intake. Brain Res 1999; 839: 227-234. 